\title{
THE INVOLVEMENT OF INDONESIAN CIVIL SOCIETY ORGANIZATIONS IN THE POLICY-MAKING PROCESS OF MIGRANT WORKERS PROTECTION IN ASEAN
}

\author{
lyan Septiyana \\ International Relations Study Program \\ Universitas Katolik Parahyangan, Bandung, Indonesia \\ Email: senyan@ymail.com
}

\begin{abstract}
More than 20 millions of ASEAN citizens work overseas as migrant workers. The contribution of migrant workers to economic development for both the destination and the origin countries are respectable. However, for some decades the policy of migrant worker protection was absent since none of ASEAN member states discusses the issue in the regional level. In fact, from the beginning of the migration process, the migrant workers often become victims of human rights violation and workers' rights violation for instance physical abuse, exploitation, harassment, and discrimination. In 2007 and 2017 ASEAN eventually agreed on migrant workers protection policies. While ASEAN is well-known as a state-centric regional organization, the policymaking process has involved some CSOs. The limited participation space in ASEAN does not hinder the CSOs to bring up the issues in the regional public sphere and to involve in the policy-making process by influencing ASEAN member states through three available spaces for non-state actors. This paper focuses on the involvement of Indonesian CSOs as in the policy-making process on migrant worker protection at the regional level.
\end{abstract}

Keywords: Indonesia, Civil Society Organization, ASEAN, Migrant worker policy, public sphere, political participation

\begin{abstract}
Abstrak
Lebih dari 20 juta warga ASEAN bekerja di luar negeri sebagai pekerja migran. Kontribusi pekerja migran terhadap pembangunan ekonomi baik bagi negara tujuan maupun negara asal patut dihargai. Namun, selama beberapa dekade kebijakan perlindungan pekerja migran tidak ada karena tidak ada negara anggota ASEAN yang membahas masalah ini di tingkat regional. Faktanya, sejak awal proses migrasi, para pekerja migran sering menjadi korban pelanggaran hak asasi manusia dan pelanggaran hak-hak pekerja seperti kekerasan fisik, eksploitasi, pelecehan, dan diskriminasi. Pada 2007 dan $20 I 7$ ASEAN akhirnya menyepakati kebijakan perlindungan pekerja migran. Sementara ASEAN dikenal sebagai organisasi regional yang berpusat pada negara, proses pembuatan kebijakan telah melibatkan beberapa OMS. Ruang partisipasi yang terbatas di ASEAN tidak menghalangi CSO untuk mengangkat isu-isu di ruang publik regional dan untuk terlibat dalam proses pembuatan kebijakan dengan mempengaruhi negara-negara anggota ASEAN melalui tiga ruang yang tersedia untuk aktor non-negara. Makalah ini fokus pada keterlibatan OMS Indonesia sebagai proses pembuatan kebijakan tentang perlindungan pekerja migran di tingkat regional.
\end{abstract}

Kata kunci: Indonesia, Organisasi Masyarakat Sipil, ASEAN, kebijakan pekerja migran, ruang publik, partisipasi politik 


\section{INTRODUCTION}

ASEAN member states (AMS) are sending and receiving countries of the migrant workers. The migration scheme of migrant workers in the region began since I970s when the economic development of Malaysia and Singapore arisen (Sayono, Wahyu, \& Ayundasari, 20I8). Every year the number of migrant workers in ASEAN increases. From 2000 to 20I7, the number of ASEAN migrant workers increase from 4.9 million to 9.8 million (UNDESA, 20I7). They spread in four main destination countries such as Singapore, Malaysia, Thailand, and Brunei Darussalam (ILO, 20I6). However, the registered number of migrant workers in the region is only about 225 thousand to 352 thousand people (ILO, 20I6), while the rest are undocumented migrant workers (Elemia, 20I7). The majority of ASEAN migrant workers is unskilled workers that work in domestic and construction fields. While most of the recruitment process involves the role of private intermediary agencies (Battistella, 20I4), both legal and illegal agencies, it makes them vulnerable to become the victim of workers' rights violation such as exploitation, physical abuse, and sexual harassment (Razak, 20II). However, since the early wave of workers migration in the region until 200os, none of ASEAN member states takes common actions to tackle the issue at the regional level (Lean, Lim Lin; Hoong, I983).

Indonesia is the biggest sending country of migrant workers in the region. The majority of the workers are working in Malaysia (Battistella, 2014), and estimated that half of the workers are undocumented (Migrant-Care, 2009). Many studies have indicated that the undocumented status makes them vulnerable to become the victim of worker rights or human rights abuses in the destination countries (Razak, 20II). The cases vary from exploitation, unpaid salary by the employer or taken by the agency, victim of sexual harassment and physical violence, sometimes drag them to be a murderers because they tried to do self-defense (Migrant-Care, 2009). Based on data from BNP2TKI (National Agency for Placement and Protection of Indonesian Workers) from 20II until 20I7, there were 89I violence cases, 4.452 unpaid salary cases, and
3.074 death cases in the destination countries (BNP2TKI, 2015, 2016, 2017).

The imbalance number between the government officials and the cases handled by the government has opened the opportunity for civil society organizations (CSOs) in Indonesia to deal with migrant worker issues. The CSOs are considered having possibilities to have closer relations with migrant worker groups since they have more experienced human resources and more flexible structures than the government. Active involvement of CSOs in dealing with migrant worker groups in Indonesia, in turn, has regional impacts. They become proactive participants in the regional forum to fight for migrant worker rights in ASEAN.

ASEAN is known as a state-centric regional organization including in the policy-making process. However, in the issue of migrant workers, ASEAN provides the participation space for CSOs to get involved. There are two regional instruments where CSOs get involved in the policy-making process. The first instrument is a regional instrument called "ASEAN Declaration on the Protection and Promotion of the Rights of Migrant Workers" that emerged in 2007. The second regional instrument is "ASEAN Consensus on the Protection and Promotion of the Rights of Migrant Workers" that emerged in 20I7. This condition brings up a question of how CSOs can involve in the policy-making process of the regional instrument of migrant workers protection in ASEAN. Considering Indonesia as the biggest sending country, this paper focuses on the involvement of Indonesia CSOs in the policy-making process of migrant workers protection in ASEAN.

\section{THEORETICAL FRAMEWORK}

This research applies a critical theory of International Relations (IR) perspective that sees political behavior of non-state actors in international politics (Hadiwinata, 20I7). ASEAN is a state-centric regional organization, in which the member states does not transfer their member sovereignty to the organization. It makes some regionalism theories such as regionalism, federalism, and multilevel gover- 
nance cannot be applied to explain non-state actors (NSA) in ASEAN (Igarashi, 20II). Furthermore, Kelly Gerard has a similar argument that IR mainstream theories cannot explain NSA in ASEAN holistically (Gerard, 20I4).

The nature of state-centric organization is clearly seen in the power of decisionmaking in ASEAN which held by government representatives. In the decision-making process, state actors positioned in the center. The regional decision-making process is decided in the government meeting such as in the head of government meeting, ministerial meeting or governmental bodies' meeting based on consensus among the governments (Margaret P Karns et al., 20I5). The illustration of ASEAN's decision-making structure is described on the following page (Chart I).

Chart I. ASEAN's Decision-Making structure

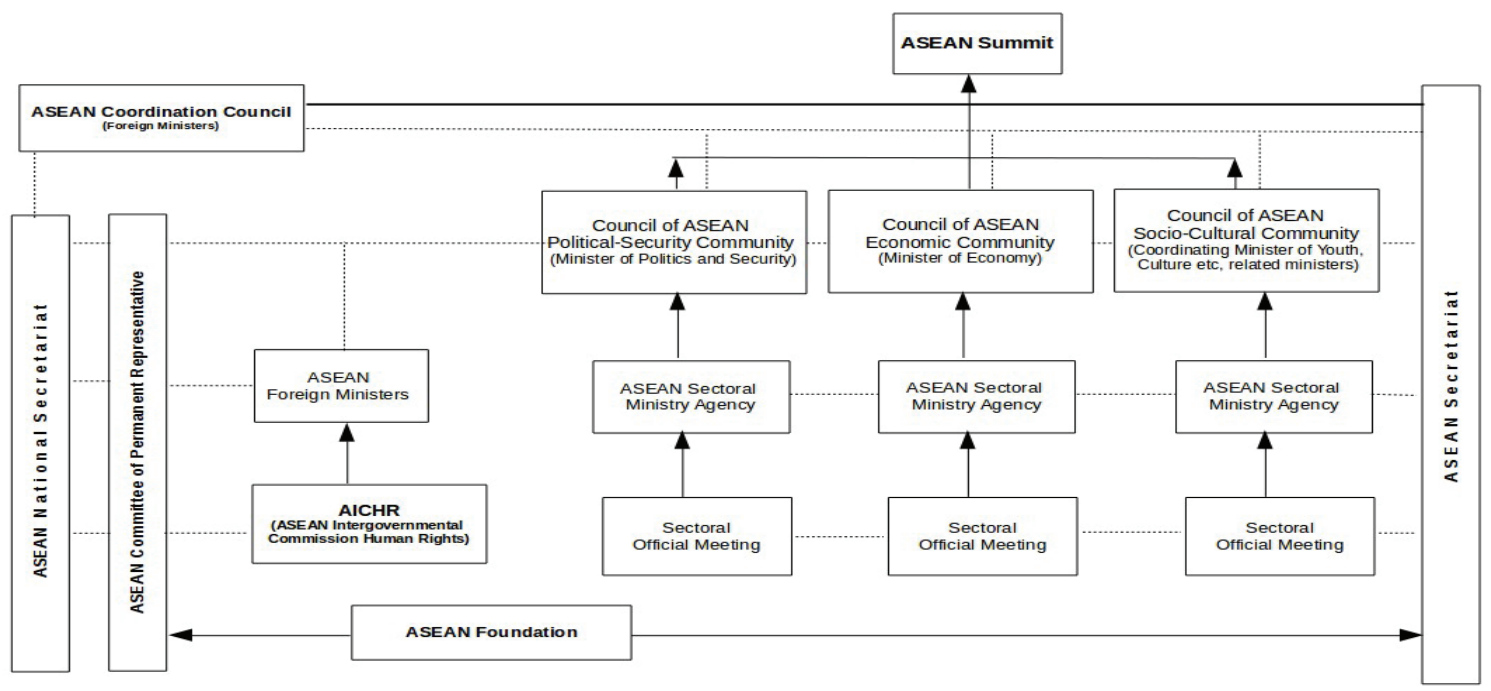

Source: Booklet "Ayo Kenali ASEAN" 2015

The chart above illustrates the hierarchical structure of ASEAN in the context of decisionmaking as written in the ASEAN Charter. Firstly, on top of the structure is Summit where the decision taken in the meeting among the head of government or the head of state. They determine a policy based on mentioned issues by ASEAN Coordination Council, ASEAN Community Council (APSC, AEC, and ASCC), and ministerial sectoral agencies. Secondly, ASEAN Community Council that consists of related ministers of AMS meets in ASEAN Ministerial Meetings (AMM) in the annual meeting to discuss various regional cooperation sectors based on respective pillars. Moreover, on this meeting there is Coordination Council (the members of the council are Foreign Ministers of AMS). The third is sectoral bodies of ASEAN Ministries that the member is ministerial-level officials. The fourth is head of sectoral bodies (ASEAN-Secretariat, 2008).
Besides, two other meetings formulate regional policy. The first is ASEAN PostMinisterial Conference (APMC), which held after foreign minister annual meetings. This meeting gives opportunity for foreign ministers to meet with their partners from dialog partner countries. The second is ASEAN Senior Official Meeting (SOM), a meeting of foreign ministries to discuss political cooperation. The meeting provides inputs for AMM, also brings together the political and defense officials of AMS (Anthony, 2005). The meeting is organized by ASEAN Secretariat that consists of Secretary-General (elected in the summit with alphabetical rotation system, be held in 5 years) and the staffs (not an employee of AMS' government, pure ASEAN Secretariat employee) (ASEAN-Secretariat, 2008). 


\section{THE SHIFT OF ASEAN PARADIGM: FROM STATE-CENTRIC TO PEOPLE- ORIENTED}

Critical theory views that the international system is constructed by states and society (Linklater, I990). ASEAN is a top-down organization, but the development of this organization cannot be separated from the influence of other interest groups such as group of experts, businesses, and civil societies. For instance, the shifting of ASEAN paradigm from "statecentrism" to "people-oriented" that provides more spaces for non-state actors to involve in the governance is the result of non-state actors influence. This shift occurred since the ASEAN Charter that was agreed upon by member states, involving civil society organizations in the draft-making process (Chavez, 2015; Collins, 2008; Igarashi, 20II)

In the ninth Summit on October 2003, ASEAN member states signed the ASEAN Concord Il to establish the ASEAN Community. The objective of the agenda is to strengthen their economic and social stability. The Community will be achieved through three pillars,pillars, namely ASEAN Political Security Community (APSC), ASEAN Economic Community, and ASEAN Socio-Cultural Community (ASCC).

The legal and institutional framework of this Community is based on the ASEAN Charter. The framework stated in Chapter I article I point 13 that ASEAN promotes "people-oriented" which means in the process of integration and community building, ASEAN promotes and encourages all sectors of society to participate. However, the use of "people-oriented" terminology in the Charter is less progressive than that formerly introduced by ASEAN Eminent Person Group (EPG) which provided more inclusive recommendations for the involvement of grass-root or civil society in the decision-making process (Morada, 2008 in Howe and Park, 20I7). The term of "peopleoriented" means that the policies are for the people (Chandra, 2009), but the inputs and responsibility of decision-making still held by ASEAN leaders (ASEAN Information Center, 20I6), whereas the term of "people-centered" suggests that the policies and principles are determined by the people (Chandra, 2009). Albeit the latter was preferred by the civil society, some ASEAN Member States objected to using the term of "people-centered" because it will create a misconception of ASEAN as a bottom-up organization (ASEAN Information Center, 20I6), in contrast to the legitimacy of member states (Gerard, 2013). Nevertheless, the adopted ASEAN Community Vision 2025 in 2015 finally emerge both terms to sustain the relevance of ASEAN in facing certain types of human security threat such as disaster, poverty, environmental issues, diseases, transnational crimes, and trafficking (Howe and Park, 20I7) $\square$.

The shift of paradigm from state-centrism to people-oriented enables CSOs to participate in the ASEAN governance. According to the article 16 of ASEAN Charter, NSA must follow the provision of Committee of Permanent Representative (CPR) which are: the member is diplomat; in line with the vision and mission of ASEAN; must follow the procedure by writing an application statement to a specific ASEAN body which they want to engage through the ASEAN Secretariat, then the body will decide the engagement procedure and will be agreed by CPR and then will convey to the Community Council (APSC, AEC, and ASCC) (ASEAN-Secretariat, 2017). CSOs that passed the assessment get some advantages in terms of giving policy recommendation to ASEAN bodies through ASEAN Secretariat, proposing a program and participate in ASEAN meeting for consultation issues, accessing documents and ASEAN Secretariat facilities (ASEANSecretariat, 20I7). However, the position of CSOs in ASEAN only becomes a transmission belt for policy implementation not as policy maker (Rüland, 20II).

According to Gerard, there are three participation spaces for CSOs in ASEAN. Those are spaces established by ASEAN, recognized by ASEAN, and created by CSOs (Gerard, 2014), as shown in Table 2, on the following page. 


\begin{tabular}{|c|c|c|}
\hline \multicolumn{3}{|c|}{ SITES OF PARTICIPATION } \\
\hline $\begin{array}{l}\text { Spaces } \\
\text { established by } \\
\text { ASEAN }\end{array}$ & Recognized space & $\begin{array}{l}\text { "Created } \\
\text { spaces" }\end{array}$ \\
\hline $\begin{array}{l}\text { CSO affiliation } \\
\text { system }\end{array}$ & $\begin{array}{l}\text { - ASEAN People's As- } \\
\text { sembly } \\
\text { - ASEAN Civil Society }\end{array}$ & $\begin{array}{l}\text { - Parallel } \\
\text { activities } \\
\text { - Protests }\end{array}$ \\
\hline $\begin{array}{l}\text { Ad hoc consul- } \\
\text { tation }\end{array}$ & $\begin{array}{l}\text { Conference } \\
\text { - Regional Tripartite } \\
\text { Social Dialogue for }\end{array}$ & $\begin{array}{l}\text { - Production } \\
\text { and dissemi- } \\
\text { nation }\end{array}$ \\
\hline $\begin{array}{l}\text { GO-NGO } \\
\text { forums }\end{array}$ & $\begin{array}{l}\text { Growth, Employment } \\
\text { and Sound Industrial } \\
\text { Relations } \\
\text { - ASEAN-ISIS Colloqui- } \\
\text { um on Human Rights } \\
\text { - Dialogue on De- } \\
\text { mocracy and ASEAN } \\
\text { Integration }\end{array}$ & $\begin{array}{l}\text { of critical } \\
\text { knowledge } \\
\text { - Target- } \\
\text { ing other } \\
\text { regional/ } \\
\text { global } \\
\text { governance } \\
\text { institutions }\end{array}$ \\
\hline
\end{tabular}

The three participation spaces for CSOs in ASEAN are different in the way they involve in policy-making. In the space established by ASEAN, CSOs must be assessed first to affiliate with ASEAN. The assessed CSOs can participate in ad-hoc consultation in the limited process of policy-making, also in the GO-NGO forum (Governmental Organization and Non-Governmental Organization) (Gerard, 20I4, p. 83-Io6). The participation is very limited and CSOs cannot contradict to the government policy (Gerard, 20I4, p. 8I). The second space, namely the space that recognized by ASEAN, CSOs can engage a dialog with ASEAN, although they are not the assessed CSOs. The participation can be obtained through ASEAN People's Assembly (APA) that formed by ASEANISIS (Institute of Strategic and International Studies) and ASEAN Civil Society Conference (ACSC) that initiated by Malaysian government which then formed a network named Solidarity for Asian People Advocacy. In the second space, CSO can criticize government policies that are not compatible with institutional interests (Gerard, 20I4, p. I07). The third space, which is created by CSO, is more independent and flexible. The goals are to draw ASEAN leader attentions and to frame an issue. The activity in this space encompasses parallel meeting with ASEAN meeting, producing alternative or critical knowledge, and approaching other global institutions to influence ASEAN such as UN and ILO (Gerard, 20I4, p. I37-I54).

\section{HUMAN RIGHTS ISSUE AS AN OPEN- ING GATE FOR CSOS}

Discussing the involvement of the CSOs in ASEAN cannot be separated from the development of human rights issues in ASEAN. ASEAN member states began to take concerns about human rights by institutionalizing human rights body in 2009, namely the ASEAN Intergovernmental Commission on Human Rights (AICHR). This body does not emerge from the initiatives of ASEAN officials, yet influenced by civil society that attempting to advance human rights in the region such as: by joining Working Group for ASEAN Human Right Mechanism (WG-AHRM) ${ }^{\mathrm{I}}$ which becomes a dialogue partner of AMM in establishing regional human rights mechanism since I998, proposing the idea through APA, and influencing the Charter drafting by expressing the idea to establish human rights body (Hsien-Li, 20II).

Human rights development in South East Asia is similar to other Asian countries. Cultural diversity makes ASEAN member states view the universal human rights in particularism perspective. This perspective views the culture of a group of people cannot be generalized as a phase of humankind cultural development (Zygadło, 20I8). It views that the standard of the universal declaration of human rights cannot be applied universally. Consequently, the establishment process of human rights in ASEAN take a long process since the first discussion in 1998.

WG-AHRM is the first human rights CSO in ASEAN that actively works to initiate a regional mechanism of human rights. WG's works began to be recognized by ASEAN since the $3 \mathrm{I}^{\text {st }}$ AMM in 1998 when ASEAN foreign ministers conducting routine official discussion with them. Until 200I, the discussions between ASEAN and the WG did not produce a substantive output. In 2002, four national human rights institutions (NHRIs) from Indonesia, Malaysia, the Philippines, and Thailand cooperated with

I WG-AHRM consists of lawyers, academics, parliamentarians, and CSO representatives 
their foreign ministers and WG organized an annual workshop to advance the process of the human rights establishment. This workshop recommended ASEAN to create a supranational human rights institution. However, it was rejected by the majority of AMS because it was considered not in line with the ASEAN way. To keep up the plan, WG changed its strategy by proposing continued dialogue and cooperation among NHRIs of AMS, ASEAN-ISIS, and other CSO groups (Hsien-Li, 2OII).

The 3rd workshop in 2003 resulted some recommendation points such as suggesting the establishment EPG and a focal point; creating NHRIs in all AMS; involving the UN and other international institution; and convincing AMS to establish human rights institution as a commitment to CRC and CEDAW. In 2004, in the $4^{\text {th }}$ workshop between ASEAN with this WG, they yielded a technical design step of regional human right mechanism establishment, and recommendation to make ASC commits with human rights including human rights of the vulnerable group such as migrant workers, women, and children. The meeting concluded with a medium-term plan and long-term plan. The medium-term plan is to have the arrangements of the rights of women and children, also the rights of migrant workers. While the long-term plan is the effort to establish NHRIs and ASEAN Charter (Hsien-Li, 2OII).

Then in July 2005, this WG met with ASEAN senior officials to discuss the implementation of Vientiane Action Program 2004 (VAP), especially in the matter of human rights. The result of this meeting, WG get the opportunity to provide its expertise and service towards VAP implementation, to establish a commission for promoting and protecting the rights of women and children, and to elaborate instrument of migrant workers protection (Hsien-Li, 20II).

While it took a long process, the fact that ASEAN has finally adhered human rights principle and has involved the CSOs in the process is an important milestone for ASEAN. The question is what makes ASEAN move forward from the state-centric to peoplecentered approach. Once the cosmopolitan society concept in the critical theory views that all human being is "citizens of a universal state of humanity" who has responsibility to create community discourse to lessen unfair exclusion forms in the society by conducting non-coercive communication or dialogue (Linklater, I998). It means, whenever the unfair condition system happens on a group of the society, the movement to change the condition through non-coercive actions such as dialogue will appear.

Parallel with Linklater, Habermas views that dialogue can create social change if a society mobilizes themselves to participate in forming public opinion and common good will in such democratic way. This dialogue is a form of self-determination to influence social condition (Habermas, 2003). Self-determination practice can be run when the society holds political participation and communication rights (Habermas, I995). Furthermore, Nancy Fraser stated that in critical theory there are two main axes of political struggle, those are redistribution that related to the class struggle and social emancipation, and recognition that related to freedom and justice and national recognition (Ferreira, 20I7).

In this case, the social condition is the regional system of ASEAN that marginalizes the migrant worker groups. CSO respond to that condition by mobilizing themselves to lead public discussions to raise this issue as a regional topic for ASEAN. It started by discussing the agenda of the establishment of a regional human rights mechanism. Refers to Habermas and Fereira, the CSO's practicing dialogue is a form of self-determination to emancipate migrant worker groups and to transform the system of ASEAN to be more participatory for them.

In the dialogue process, the public opinion shaped by society through discussions in the public sphere. This sphere is an open public space where public policy can be legitimized through discussions of a specific issue to shape public opinion (Habermas, I99I). Moreover, Habermas stated that public sphere can be described as a network to communicate information and point of view both affirmative 
and negative attitudes which can be led as public demands to establish public policy (Habermas, I996).

Bernhard Peters and Wessler describe public sphere as a multilayer sphere that consists of "center" and "periphery". In the center, there is a government and its bodies that can legitimize a public policy. While in the periphery, there are some entities such as mass media, civil society, research opinion, and various communication and public networks. The role of the periphery is intermediary between society and the government in the core, which conveys the interest of public opinion to the government (Benson, 2009).

Therefore, civil society has the power to influence the society. According to Habermas, civil society is a group of people that consists of non-governmental networks group, noneconomic and voluntary association that leans on communication structure in the public sphere (Crawford, 2009). The role of civil society in the public sphere is to strengthen what appears in it (Spång, 20I7). A CSO comes from a group of people who have problems, and CSOs that fight for labor rights in ASEAN are formed or initiated by groups of migrant workers themselves. In the regional governance, civil society organizations practice their activity in the networks that transcend the national border and create networks of networks (Stefan Rother \& Piper, 2014). These joint networks consist of local and global groups, and strengthen the corrective voice from society (Ghaus-Pasha, 20I4).

In this case, Indonesian CSOs in order to emancipate migrant worker groups affiliate themselves with the networks of networks which also interact with global institution. These networks enable them to involve in ASEAN policy-making process for advocating the regional policies of migrant workers protection. This multi-actors alliance is called by "new diplomacy" in which it has been effective ways to construct new global and universal norms through multilateral institutions independently as an alternative to prevailing Great Powersinfluenced international rules (Margiansyah, 20I8). Case of CSO in ASEAN is an instance of effective "new diplomacy" practice in the last two decades.

\section{INDONESIA AND MIGRANT WORKER ISSUES IN ASEAN}

Indonesia is the biggest sending countries of migrant workers in ASEAN, and the majority of them works in Malaysia. However, about more than a million workers are undocumented migrant workers (Migrant-Care, 2009). Consequently, they are facing various problems in the destination countries. These cases continually repeated every year. In 2017, registered there were more than I.80o Indonesian migrant workers became victims of human trafficking, 215 died in the destination countries, and I.700 exploited (TIFA-Foundation, 2018). These recurring cases made some Indonesian CSOs working on the issue of migrant workers to become proactive participants in the regional forum to fight for migrant worker rights in ASEAN.

The domestic economic condition becomes the full factor for Indonesian people to work abroad. This began since the fall of the Soeharto era in 1997, when the inflation rate increased up to $77 \%$ and led to the increasing poverty rate from 20 million to Ioo million people (Hays, 2015). To recover the economic condition, the Indonesian government allowed the establishment of foreign companies with full share of the ownership and supported by cheap labors. Consequently, the value of local wage dropped and the employment availability is limited (Martyn, 20I8).

For some Indonesians, working abroad is an alternative to get more income to fulfill their basic and family needs. Besides, Indonesia gets economic supports from migrant workers when they send remittances to their family (Nahar and Arshad, 20I7). The number of remittances from Indonesian migrant workers is enormous. Based on BNP2TKI data, the minimum inflow per year was 6.73 billion dollars and the highest was 9.43 billion dollars per year (BNP2 TKI, 20I7). Even though they support the economic state, but the state puts less attention to protect them. Indonesian migrant workers face such 
problems since pre-recruitment, repatriation, and reintegration process (Yazid, 2013). They face some problems such as mistreatment, violence, harassment, exploitation, and worker rights abuse.

Some factors make Indonesia migrant workers facing those problems. At least there are four problems based on the stakeholder factor, those are government, intermediary agency, employer, and migrant workers. Firstly, government of sending countries is less responsive to the issue of migrant workers. The capacity of person-in-charge in the destination country is inadequate to handle migrant worker issues (a representative of Brunei $\mathrm{CSO}$, 20I8). In addition, the limited number of institutions that handle the case makes the problem even worse. For example, Indonesia only has 13 embassies and consular that mandated to serve migrant workers issues in 12 destination countries (Azis, 2018). Government is uncertain in punishing problematic agencies and the owner (Santoadi, 20I8). On the other side, the government of destination country such as Singapore has not ratified yet the ILO Convention I970 (no.I3I). Consequently, no minimum wages can be applied for all workers in Singapore (Bal and Chok, 20I8). Moreover, there is no strict punishments from the government to the employer that violates human rights and discriminates migrant workers (Bal, 20I8).

The second problem is on the intermediary private agency. They often are not aware of their responsibility to protect migrant workers from the recruitment to the repatriation process. Many of them see migrant workers as commodities, not as humans with rights (Samydorai and $\mathrm{Bal}, 2018)$. The third problem comes from the employer who treats migrant workers in such an inhumane manner (Bal and Chok, 20I8). The last is the problem that comes from the migrant workers. Sometimes migrant workers come to a destination country with lack of skill and local culture, which makes them difficult to communicate with the employer (Kusuma, York, \& Wibowo, 2015).

The limited capability of those stakeholders, consequently, requires another actor to fill the gap. CSO is an entity that can be a third actor that can help to voice up collective individual interest (Hadiwinata, 2003), including in the case of migrant workers. Flexibility of the CSO to maintain its relations with the targeted groups (Hadiwinata, 2003), makes them close with the society and know the real social condition. CSOs' concern on migrant worker rights cannot be separated from the fact that the government has less concern to citizens that work overseas. The absence of regulation to protect them was the evidence. Consequently, when migrant workers face problems, the settlement is difficult since there is no legal regulation (Sumardiani, 20I4). Thus, CSOs put the interests to make the government aware of the need for legal regulations that will protect migrant workers.

In Indonesia, there are some CSOs which work and concern about migrant worker issues. Their activities encompass providing legal advice, training for migrant workers, collecting data, and policy advocacy. In the national level, when the draft law No. 25 of 1997 concerning about employment excluded the migrant workers, more than Ioo CSOs responded by forming a consortium named KOPBUMI to push Indonesia government to ratify the I990 International Convention on the Protection of the Rights of All Migrant Workers and Members of their Families (Yazid, 2013). As a result, in 2004 Indonesian government began to put attention to migrant workers by legislating the national law No. 39 of 2004.

Albeit the consortium successfully pushed the Indonesian government to establish the national law of migrant workers protection, the violence cases against migrant workers still occurred. Therefore, some consortium members continue to actively handle migrant worker cases. First, Solidaritas Perempuan (SP) that established since I990 and concerns about women rights. Even though they concern about women, they also help men migrant workers. Based on their annual report from 2012 until 2016, there were 132 cases handled by them (Solidaritas-Perempuan, 2015, 2017). Second, Migrant CARE, a CSO that established in 2004 and works on policy advocacy by conducting 
protest to government, giving legal aid, conducting research, and participating in the global institution meetings, such as in UN and ASEAN (Yazid, 2015). Third, Serikat Buruh Migran Indonesia (SBMI), which established in 2003 and pioneered by KOPBUMI. Since 2006, SBMI has become a trade union for migrant workers. From 2012 to 20I4, they had received 32I cases such as unpaid salary, human trafficking, personal document taking, sudden termination of employment, violence and sexual harassment which experienced by 157 women and I64 men (SBMI, 20I4) $\square$. Fourth, Lembaga Bantuan Hukum (LBH) Jakarta, which established in I996 as a private institution that giving legal aid for the poor ("Catatan Akhir Tahun LBH Jakarta 20I7: Redupnya Api Reformasi,” 20I7), and legal assistance to the migrant workers. LBH Jakarta in cooperation with its partners to provide complaint mechanism that easily accessed by migrant workers (LBH Jakarta, 20I8).

These CSOs form networks both at the national and international level to augment the influence. Moreover, these CSOs affiliated with the national network named Jaringan Buruh Migran (JBM) and Human Rights Working Group (HRWG) in the regional level. JBM was established in 2014 as a transformation of the advocation networks of the draft law No.39/2004. Within JBM, CSOs can push the government to widen the scope of protection, not only in the national level but also in ASEAN. The activity of JBM policy advocacy, issue campaign, and communicating migrant workers issue with other networks.

Other network is Human Rights Working Group (HRWG), which established since February 2003. This network is a coalition of Indonesian CSOs that concern about human rights issues including the rights of migrant workers (Awigra, 20I8). As a network for human rights CSOs, HRWG not only focuses on the national level, but also on the international level such as ASEAN (HRWG, 20I7). HRWG is elected as the national secretariat of Indonesian CSO for ASEAN Forum on Migrant Labour (AFML) by the CSO regional network named Task Force of ASEAN Migrant Workers (TFAMW) (Awigra, 20I8). TFAMW was established in 2006 as the result of the cooperation between the working group of ASEAN Human Rights Mechanism (WG-AHRM) and Solidarity for Asian People Advocacy (SAPA). Then, TFAMW becomes a consultation partner of ASEAN concerning migrant workers protection issue (TFAMW, 2009).

The democratic condition of Indonesia which is more advanced than other ASEAN member states, has raised a sense of responsibility to Indonesian CSOs to make ASEAN more concerned about human rights issues. As stated by Awigra, a manager program of HRWG for ASEAN project, the interest of Indonesian CSOs is to advance human rights in the region and migrant worker rights is part of it.

\section{INDONESIAN CSOS IN ASEAN POLICY-MAKING PROCESS OF MIGRANT WORKER PROTECTION}

For some decades, in ASEAN there was no regional regulation of migrant worker protection. While the majority of Indonesian migrant workers work in ASEAN countries such as in Malaysia and Singapore. The violence case of Indonesian migrant workers is high, and difficult to be solved at the regional level since there was no regional instrument on this matter. This fact raised the awareness that to solve the complexity of migrant worker issues, cooperation of multi-stakeholders in the regional level is required. While ASEAN has shifted its paradigm to people-oriented, state actors still hold the position of decision-maker in the regional policy-making process. It makes the participation space for CSOs in the policymaking process up to this time limited. To break the limit, Indonesian CSOs interact with other CSOs in the region that have similar concerns. Then, they creates a regional network enabling them to involve in ASEAN governance.

The regional interaction between CSOs creates regional networks called TF-AMW. This network was established to arrange a policy framework initiatives to protect ASEAN migrant workers (Samydorai, 20I8). Haryanto, a national leader of SBMI, stated that regional policy proposal of migrant workers protection 
set by all of the CSOs through the networks consisting of human rights CSOs and trade unions. Refer to Linklater, it can be argued that this effort is a form of emancipation development established by CSO conducting international interaction in ASEAN.

To involve in the policy-making process, Indonesian CSOs conduct their activities in the spaces available in ASEAN, those are established space, the recognized space, and the created space. First of all, the recognized space by ASEAN, Indonesian CSOs participated in the ASEAN Civil Society Conference (ACSC) which was parallel with the ASEAN Summit in 2006. This conference created the TFAMW, which becomes a regional network for ASEAN CSOs concerning about migrant workers rights. This network was also supported by other networks such as Migrant Forum in Asia (MFA).

Secondly, Indonesian CSOs through their participation in the TFAMW made use of the established participation space in ASEAN. They utilized the moment when the ASEAN Eminent Person Group (EPG) established the ASEAN Charter. As the EPG partners, they involved in the ad-hoc consultation process. Thirdly, Indonesian CSOs with the TFAMW and others networks used their own "created space" by organizing parallel meetings to produce an alternative policy proposal that can be submitted to ASEAN. Furthermore, they conducted a campaign which targeted their government and ASEAN leaders, and then interacted with the ILO and the United Nations to drive the ASEAN leaders.

There are two regional policy instruments of migrant workers protection in ASEAN. The first regional policy instrument is the "ASEAN Declaration on the Protection and Promotion of the Rights of the Migrant Workers", which agreed in the I2th ASEAN Summit on I3 January 2007 (ASEAN-Secretariat, 2007), and known as the 2007 Cebu Declaration of Migrant Workers. The Cebu Declaration is the first specific regional instrument of migrant workers protection in ASEAN. The declaration was adopted from CSO policy proposal named "Civil Society Position Paper upon an ASEAN
Instrument on The Promotion and Protection of The Rights of Migrant Workers". The proposal from eight CSOs of ASEAN member states except Myanmar and Brunei Darussalam (Samydorai, 20I8).

The proposal was established since 22 April 2006 in the first regional meeting attended by 40 representatives of $\mathrm{CSO}$ consisting of trade unions and migrant worker organizations from ASEAN member states (TFAMW, 2006). The proposal was a request from WG-AHRM to CSOs as part of VAP's (Vientianene Action Program 2004) mandate. It was based on CSOs' research finding. This meeting organized by human rights and worker rights CSOs from Asia, such as FORUM-ASIA and Migrant Forum in ASIA (MFA) and supported by Canadian International Development Agency through the program SEARCH-CIDA, ILO, Global Union Federation (GUF), and United Nations Inter-Agency Project on Human Traffickingng (UNIAP) (TFAMW, 2006).

The meeting discussed seven issues related to migrant workers problems. First, the issue of gender equality iremuneration (ILO IOo), discrimination (ILO III), and government periodical report of CEDAW implementation. Second, the issue of poverty and development, the needs to change the perspective of the sending countries government that see migrant workers as a commodity. Third, people smuggling and trafficking. Fourth, exploitative intermediary agency and the needs to adopt ILO I8I. Fifth, developing national law and policies and ILO regional framework. Sixth, omplaint mechanism and regional periodical report system. Seventh, other issues such as discrimination, freedom of association, and the clarity of the working system and the needs of the ILO multilateral framework in ASEAN. The meeting yielded a proposal recommendation that submitted to ASEAN. The submission process is illustrated in chart 3 below. 
Chart 3. Position of Indonesian CSO in the process of the Cebu Declaration

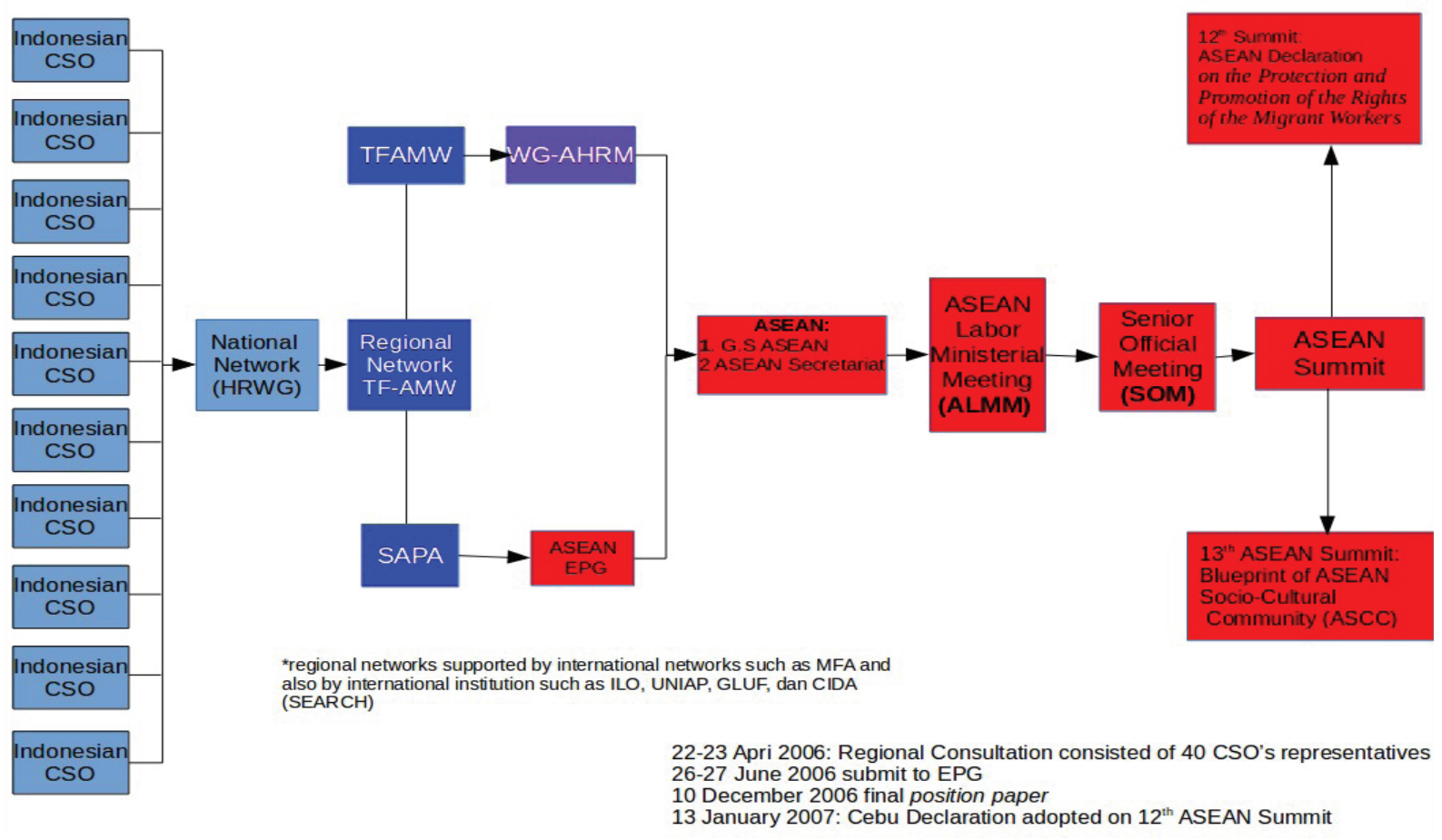

Source: Compiled by authors based on TFAMW documents

The chart, on the previous page, illustrates that the policy proposal of CSO submitted to ASEAN through two channels. The first channel is within the SAPA network through EPG channel in the consultation process of ASEAN Charter establishment. By means of the network, ASEAN CSOs can interact with the EPG in their respective countries to follow up the recommendation. Later, the proposal was adopted as the blueprint of ASEAN SocioCultural Community. The second channel is through the WG-AHRM network that submitted the recommendation to the ASEAN Labour Ministers Meeting (ALMM) and Senior Officials Meetings (SOM). Later on the I2th ASEAN Summit on 2007, ASEAN adopted the document as ASEAN Declaration on the Protection and Promotion of the Rights of the Migrant Workers.
The second regional instrument on migrant workers is the "ASEAN Consensus on the Protection and Promotion of the Rights of Migrant Workers" that agreed by ASEAN member states at the 3Ist ASEAN Summit on I4 November 2017 (ASEAN Secretariat, 2017). Moreover, this instrument is a mandate from the article $22^{\text {nd }}$ of the previous $2007 \mathrm{Cebu}$ Declaration. The CSOs took an initiative to offer themselves to get involved in the instrument-making process of migrant workers protection which not only in line with the vision and mission of ASEAN, but also in line with the ILO labor conventions (TFAMW, 2007) $\square$. The drafting process of the proposal is described in the chart 4. 
Chart 4. CSO Policy Proposal-drafting Process

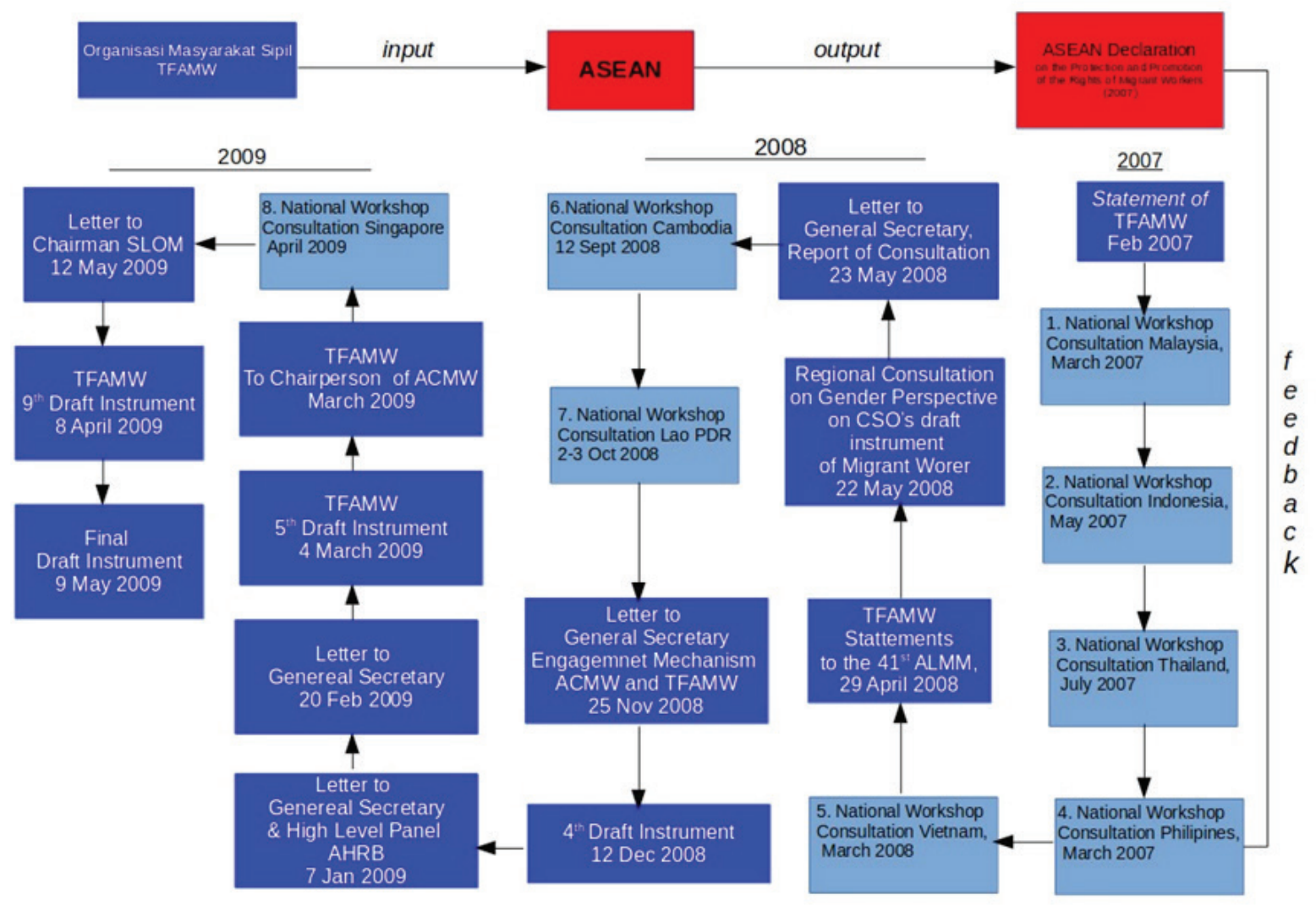

Source: compiled by the author based on TFAMW documents

Chart 4, on the previous page, illustrates that the policy proposal began to be arranged from March 2007 until May 2009 by conducting eight national CSO consultation meetings in Malaysia, Indonesia, Thailand, Filipina, Vietnam, Cambodia, Lao PDR, and Singapore. Besides those national consultations, these CSOs organize seven regional consultation meetings nevertheless. The output of the meeting is a set of recommendation statement for ASEAN member states and the government of the host country. The recommendation for ASEAN consists of the ratification of the eight core ILO conventions and UN Convention on the Protection of the Rights of All Migrant Workers and Members of Their Families (UN$\mathrm{CMW}$ ) the requirement for establishing report mechanism of the instrument implementation, the requirement for accurate data of migrant workers number, gender-based policies, etc.
While the recommendation for national government comprises from the ratification of UNCMW, establishing the policy that regulates migrant workers recruitment according to the ILO standard, providing solutions for the threat of migrant workers, and providing one-stop service center.

The proposal constantly changes along with the following consultation meetings. They completed the proposal in May 2009 named "Civil Society Proposal: ASEAN Framework Instrument on the Protection and Promotion of the Rights of Migrant Workers". There are three core principles of CSOs' proposal, those are legally binding, non-discriminative, and family unification (Pasha, 20I8). The proposal then submitted to the ASEAN Secretariat and presented in the Senior Labor Official Meeting (SLOM) in Lao PDR (TFAMW, 2009). 
In the negotiation process, sending states were represented by the government of Indonesia and the Philippines. While the receiving states were represented by Malaysia and Thailand. The different interest between sending and receiving states makes the negotiation though. Only three out of ten countries which agreed to make the instrument legally binding, which were Indonesia, Philippines, and Vietnam. Thailand was not in agreement to this instrument. On the other side, Singapore and Malaysia only agreed with legally binding (Pasha, 2018). The agreement achieved and approved as a regional instrument in 20I7. The flow of proposal policy become the instrument of Consensus and the position of the Indonesian $\mathrm{CSO}$ in the consensus-making process is described on Chart 5.

Chart 5. Position of Indonesian CSO in the process of ASEAN Consensus

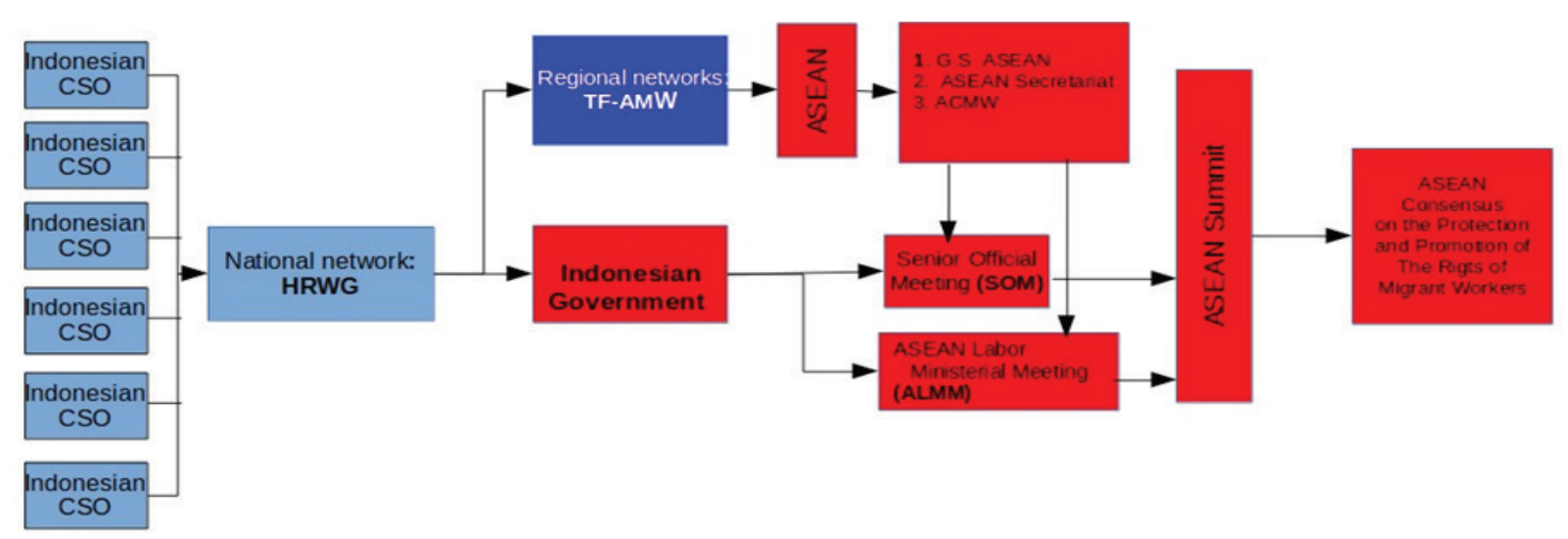

Source: compiled by the author based on TFAMW documents

The previous chart illustrates that the instrument of consensus agreed in the ASEAN Summit, and processed through various ASEAN meetings. The consensus is a policy of migrant workers, therefore the proposal discussed in the Labor Ministerial Meeting (ALMM) and SOM. This proposal came from the ASEAN CSOs which conveyed to ASEAN through two channels, ASEAN Secretariat and government of member states.

As mentioned above, policy proposal of CSO is the result of eight national level and seven regional level consultation meetings among the CSOs. The second national consultation meeting held in Indonesia in May 2007. TFAMW with Indonesian CSOs provided some recommendations to the Indonesian government to develop its national policy of migrant issues and to the ASEAN to develop a regional instrument of migrant workers protection (TFAMW, 2007).

In the case of Indonesians CSO involvement in the policy making process, there are two national networks which become the partner of TFAMW, namely HRWG and ASPEK (representing the trade union). HRWG, which affiliated with regional network TFAMW, gave them two ways of participation. First, through HRWG, they submitted their proposal direct to Indonesian government agencies that represented ACMW, those are the Ministry of Foreign Affairs and the Ministry of Manpower. The second way is, CSO within HRWG submitted their policy proposal through the regional network TFAMW to ACMW, ASEAN General Secretary, and then submit the proposal to SLOM. They finally presented the proposal in the SLOM meeting in Vientiane, Lao PDR in 2009 (TFAMW, 2009: 2010).

Before these networks participated in the regional meeting, they did research first to make their policy recommendation is accurately needed by society. They submitted and discussed the recommendation with other ASEAN CSOs in the regional consultation meeting led by TFAMW. Then, TFAMW compiled the recommendation policy and 
submitted to ASEAN through ACMW. Besides their own initiatives, the success in drafting previous policy proposals made ACMW (the ASEAN Committee on Implementation the declaration of protection and promotion of the rights of migrant workers) asked the TFAMW to organize the establishment of the policy proposal (TFAMW, 20I0).

Overall, the active participation of Indonesian CSOs in the consultation meeting of policy proposal drafting both in the national and regional level cannot be separated from the progress of democratic condition of Indonesia. The democratic climate in Indonesia after 1998 has paved the way for Indonesian CSOs to actively involved in the governance. Before the reformation era, there was only one labor organization named Federasi Buruh Seluruh Indonesia (FBSI) which controlled by the government (Kuwado, 20I6) $\square$. On that period, the decisionmaking was not transparent to the public because there was no space for CSO to get in. Then, since the democratization that supported by the development of freedom of expression, thousands of CSOs emerge and vocalize their voice in the public sphere. Furthermore, the emergence of good governance discourse in the public institutions enable CSOs to engage with many aspects such as monitoring government works, policy advocacy to protect the weak, empowering specific groups, and environmental protection (Antlöv, Ibrahim, \& Tujil, 2005) $\square$.

\section{CONCLUSION}

Human rights issue is the opening door for ASEAN CSOs to participate in ASEAN governance, specifically in the policy-making process. WG-AHRM is the pioneer of human rights $\mathrm{CSO}$, that recognized by ASEAN which successfully influence the agenda of human rights development in ASEAN. Albeit the CSO participation space in ASEAN governance is limited, WG-AHRM with its CSO network can influence the birth of some regional instruments that concern about human rights, such as VAP in 2004, Cebu Declaration and ASCC Blueprint in 2007, ACMW in 2007, ASEAN Commission for Women And Children (ACWC) in 20Io, and ASEAN Consensus on Migrant Workers in 2017.
While the participation space is limited, to get involved in the policy-making process of the migrant worker protection, Indonesian CSO uses the available space in ASEAN. Firstly, they use recognized space by participating in the ACSC to expand, to create, and to join the regional networks. Secondly, they create their own created space through those networks, where they do some activities such as parallel meeting to produce alternative policy recommendations and interact with the UN and ILO to influence the ASEAN leaders. The support of the UN and ILO empowers them to use the established space. It can be seen when they became one of ASEAN EPG partners in ASEAN Charter making process and the policy drafting process of migrant workers protection.

Based on those taking steps, Indonesian CSO with its networks reconstructs ASEAN system not by violence but with peaceful dialogue in the public sphere. The success of the involvement of Indonesian CSOs further cannot be separated from the progress of democratic condition of Indonesia, where political participation and communication rights to discuss the social issue in the public sphere is more open than before 1998 . They intend to bring the progress into the regional level. While in the regional public sphere, the position of Indonesian CSOs is similar with other CSOs in the "periphery" layer, but democratic political system is the strength for Indonesian CSOs to convey the public opinion to the government of ASEAN member states at the "center" as decision-maker.

\section{REFERENCES}

Acharya, A. (200I). Constructing a Security Community in Southeast Asia: ASEAN and the problem of regional order (First). London: Routledge.

Aldaba, F. T. (20I4). Global and Asian Perspective on International Migration. In G. Battistella (Ed.) (pp. 197-224). New York: Springer. https://doi. org/I0.1007/978-3-319-083I7-9

Ang, A., Baruah, N., Imson, M., \& Lautenschlager. (2015). Progress of the implementation of Recommendations adopted at the 3rd - 6th ASEAN Forum on Migrant Labour meetings: Background paper to the 7th AFML. Bangkok. 
Anthony, M. C. (2005). Regional Security in Southeast Asia: Beyond the ASEAN Way. Singapore: ISEAS Publication.

Antlöv, H., Ibrahim, R., \& Tujil, P. van. (2005). Ngo Governance and Accountability in Indonesia: Challenges in A Newly Democratizing Country. ICNL. Retrieved from http://www. icnl.org/research/library/files/Indonesia/ Peter_NGO accountability in Indonesia July 05 version.pdf

ASEAN-Information-Center. (2016). Between the people-oriented and people-centered ASEAN Community? Retrieved from http:// www.aseanthai.net/english/ewt_news. php?nid=1005\&filename=index

ASEAN-Secretariat. (2007). ASEAN Document Series 2006.

ASEAN-Secretariat. (2009). Summary Record of the 2nd ASEAN Forum on Migrant Labour.

ASEAN-Secretariat. (20I7a). ASEAN Engagement with Entities. Jakarta.

ASEAN-Secretariat. (20I7b, November). ASEAN Leaders commit to safeguard the rights of migrant workers. Retrieved from http:// asean.org/asean-leaders-commit-safeguardrights-migrant-workers/

ASEAN. (n.d.). History the Founding of ASEAN. Retrieved March 20, 20I9, from https://asean. org/asean/about-asean/history/

ASEAN. (20I2a). DECLARATION OF ASEAN CONCORD II (BALI CONCORD II). Retrieved March 20, 2019, from https:// asean.org/?static_post=declaration-of-aseanconcord-ii-bali-concord-ii

ASEAN. (20I2b). The Declaration of ASEAN Concord, Bali, Indonesia, 24 February 1976. Retrieved March 20, 2019, from https:// asean.org/?static_post=declaration-of-aseanconcord-indonesia-24-february-I976

B. Guy Peters, \& Borras, S. (2010). Governance and European Integration. New York: Palgrave Macmillan.

Bakry, U. S. (2016). Metode Penelitian Hubungan Internasional. Yogyakarta: Pustaka Pelajar.

Battistella, G. (20I4). Asian Perspective on International Migration. Springer.

Benson, R. (2009). Shaping the Public Sphere: Habermas and Beyond. The American Sociologist, I75-I97. https://doi.org/I0.I007/ SI2108-009-907I-4

Berg, B. L. (200I). Qualitative Research Methods for the Social Sciences. Pearson/Allyn \& Bacon.
Börzel, T. A., \& Hüllen, V. van. (20I5). Governance Transfer by Regional Organizations: Patching Together a Global Script. In T. A. B. V. van Hüllen (Ed.) (First, pp. 3-22). New York: Palgrave Macmillan.

Budd, J. M. (20I2). Critical Theory dalam The SAGE Encyclopedia of Qualitative Research Methods. (L. M. Given, Ed.). Thosand Oaks: SAGE Publication: SAGE Publication, Inc.

Burke, A. (2008). An Introduction to International Relations Australian Persepective. Cambridge: Cambridge University Press.

Buttigieg, J. A. (2009). Perspective on Gramsci: Politics, Culture and Social Theory. In J. Francese (Ed.). New York: Ro.

Catatan Akhir Tahun LBH Jakarta 20I7: Redupnya Api Reformasi. (20I7).

Chandra, A. C. (2009). Civil Society in Search of an Alternative Regionalism in ASEAN. International Institute for Sustainable Development.

Charanpal S. Bal, \& Gerard, K. (20I7). ASEAN's governance of migrant worker rights. Third World Quarterly. https://doi.org/Io.Io8o/oI4 36597.2017.1387478

Chavez, J. J. (20I5). Transnational Social Movements in ASEAN Policy Advocacy: The Case of Regional Migrants' Rights Policy. UNRISD. Retrieved from http://www.unrisd.org/802

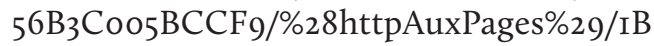
C597956IF5AACoCi257E37004CBC9o/\$file/ Chavez.pdf

Chavez, J. J. (2007). Social Policy in ASEAN: The Prospects for Integrating Migrant Labour Rights and Protection. Global Social Policy, SAGE. https://doi.org/Io.II77/I4680I8I07082239

Chernoff, F. (2007). Theory and Metatheory in International Relations. New York: Palgrave Macmillan.

Chheang, V. (2015). Migrant Workers in a People-Centered ASEAN Community and ASEAN-Japan Cooperation. Japan Center for International Exchane.

Collins, A. (2008). A People-Oriented ASEAN: A Door Ajar or Closed for Civil Society Organizations? Contemporary Southeast Asia, 30(2), 313-33I. https://doi.org/IO.I355/cs30-2g

Crawford, N. C. (2009). Critical Theorist and International Relations. In Jenny Edkins \& N. Vaughan-Williams (Eds.) (pp. I87-I98). New York: Routledge.

Creswell, J. W. (2012). Research Design: Qualitative, Quantitavie, and Mixed Methods Approaches (4th ed.). London: SAGE Publication Ltd. 
Culla, A. S. (2006). Rekonstruksi Civil Society: Wacana dan Aksi Ornop di Indonesia. Jakarta: Pustaka $\mathrm{LP}_{3} \mathrm{ES}$ Indonesia.

Elemia, C. (20I7). Undocumented migrant workers: Hidden and helpless in ASEAN. Retrieved from https://www.rappler.com/world/ regions/asia-pacific/ı6II27-plight-undocumented-migrant-workers-asean

Fenny Sumardiani. (2014). Peran Serikat Buruh Migran Indonesia dalam Melindungi Hak Tenaga Kerja Indonesia di Luar Negeri. Pandecta, 9(2).

Ferreira, M. F. (20I7). International Relations Theory. In Stephen McGlenchey Rosie Walters \& C. Scheinpflug (Eds.) (pp. 49-55). Bristol: E-International Relations Publishing.

Francese, J. (20I0). Perspective on Gramsci: Politics, Culture and Social Theory. In J. Francese (Ed.). New York: Routledge.

Geiger, A. Y. (20I5). Regional Frameworks for Managing Migration and the Role of Civil Society Organizations. Japan Center for International Exchange.

Gerard, K. (2013). From the ASEAN People's Assembly to the ASEAN Civil Society Conference: the boundaries of civil society advocacy. Contemporary Politics, I9(4), 4II-426. https:// doi.org/Io.Io80/13569775.20I3.835II3

Gerard, K. (20I4). ASEAN's Engagement of Civil Society Regulating Dissent. New York: palgrave Macmillan.

Ghaus-Pasha, A. (2014). Role of Civil Society Organization in Governance. In 6th Global Forum on Reinverting Government towards Participatory and Transparency Governance.

Goodman, J. (2008). an Introduction to International Relations Australian Persepective. In Richard Devetak Anthony Burke \& J. George (Eds.). Cambridge: Cambridge University Press.

Habermas, J. (I99I). The Structural Transformation of Public Sphere. Massachusetts: MIT Press.

Habermas, J. (I996). Between Facts and Norms. Massachusetts: MIT Press.

Hadiwinata., Bob S. (2003). Politics of NGOs in Indonesia : Developing Democracy and Managing a Movement RoutledgeCurzon Research on Southeast Asia. London: Routledge-Curzon.

Hadiwinata, Bob Sugeng. (20I7). Studi dan Teori Hubungan Internasional: Arus Utama, Alternatif, dan Reflektivis. Jakarta: Yayayasan Pustaka Obor Indonesia.

Haliim, W. (20I6). Demokrasi Deliberatif Indonesia: Konsep Partisipasi Masyarakat dalam
Membentuk Demokrasi dan Hukum yang Responsif.

Hays, J. (20I5). I997-98 ASIAN FINANCIAL CRISIS IN INDONESIA: Poor Indonesians and the Asian Financial Crisis in Indonesia. Retrieved from http:/factsanddetails.com/indonesia/ History_and_Religion/sub6_Ic/entry-3962. html

Howe, B. and, \& Park, M. J. (20I7). The Evolution of the "ASEAN Way": Embracing Human Security Perspectives. Asia-Pacific Social Science Review, I6, I-I5. Retrieved from http:// apssr.com/wp-content/uploads/20I8/04/IRA_Howe-03I4I7.pdf

HRWG. (20I7). Evaluasi Rekomanedasi AFML (ASEAN Forum on Migrant Labour). Jakarta: HRWG.

Hsien-Li, T. (20II). The ASEAN Intergovernmental Commission on Human Rights: Institutionalising Human Rights in Southeast Asia. Cambridge: Cambridge University Press.

Igarashi, S. (20II). The New Regional Order and Transnasional Civil Society in Southeast Asia: Focusing on Alternative Regionalism from below in the Process of Building the ASEAN Community. World Political Science Review, 7(I). https://doi.org/I0.2202/I935-6226.1106

ILO. (2008, March). the 30Ist of ILO Bodies' Report Agenda. Retrieved from https://www.ilo. org/wcmsp5/groups/public/---ed_norm/--relconf/documents/meetingdocument/ wcms_o906Report

ILO. (20I2), the 5th AFML Recommendation.

ILO. (2013a). Background paper: Progress on the implementation of the recommendations adopted at the 3 rd and 4 th ASEAN Forum on Migrant Labour. In ILO.

ILO. (2013b). the 6th AFML Recommendation.

ILO. (2OI4a). the 7th AFML Recommendation.

ILO. (20I4b). The ASEAN Forum on Migrant Labour Background Information Booklet / Tripartite Action for the Protection and Promotion of the Rights of Migrant Workers in the ASEAN Region (ASEAN TRIANGLE project) ; ILO Regional Office for Asia and the Pacific. Bangkok. Retrieved from http://www.ilo.org/ asia/publications/WCMS_3I0994/lang--en/ index.htm

ILO. (20I5a). the 8th AFML Recommendation.

ILO. (20I5b). The ASEAN Forum on Migrant Labour (AFML): background information booklet / Tripartite Action for the Protection and Promotion of the Rights of Migrant Workers in the ASEAN Region (ASEAN TRIANGLE 
project) ILO Regional Office for Asia and the Pacific. Bangkok.

ILO. (2016). the gth AFML Reco.

ILO. (20I7). the Ioth AFML Recommendation.

Irianto;, S., \& Truong, T.-D. (2013). Migration, Gender, and Social Justice: Perspective on Human Insecurity. New York: Springer.

Johnson, P. (2006). Habermas: Rescuing the Public Sphere. New York: Routledge.

Jones;, D. M., \& Smith, M. L. R. (2006). ASEAN and East Asian International Relations: Regional Delusion. Massachusetts: Edward Elgar Publishing.

Kellner, D. (20I4). Reimagining Public Space: The Frankfurt School in the 2Ist Century. In Boros \& Glass (Eds.) (pp. 20-2I). New York: Palgrave Macmilan.

KEMLU-RI. (20I5). Ayo Kenali ASEAN. Jakarta.

Kjell A. Eliassen, \& Arnesen, C. B. (2007). European Union and New Regionalism Regional Actors and Global Governance in a Post-Hegemonic Era. In M. Telò (Ed.). Burlington: Ashgate.

Kusuma, A. J., York, M. R., \& Wibowo, R. H. (20I5). Violence against Indonesian Migrant Workers-A Causal Analysis. Jurnal Hubungan Internasional, 4 .

Kuwado, F. J. (2016). Hari Buruh di Indonesia, dari Rezim Soeharto sampai Era Jokowi Artikel ini telah tayang di Kompas.com dengan judul "Hari Buruh di Indonesia, dari Rezim Soeharto sampai Era Jokowi.” Retrieved from https://nasional.kompas. com/read/20i6/05/oi/0930048I/Hari.Buruh. di.Indonesia.dari.Rezim.Soeharto.sampai.Era. Jokowi?page $=$ all

Larga, R., Tunon, M., \& Baruah, N. (2013). Background Paper: Progress on the implementation of the recommendations adopted at the 3rd and 4th ASEAN Forum on Migrant Labour. Bangkok: ILO Regional Office for Asia.

Lean, Lim Lin; Hoong, P. C. T. (1983). Migrant Workers in Asean: A Review of Issues and Implications for Government Policies. International Migration, 2I(2), 277-287. https://doi. org/Io.IIII/j.I468-2435.I983.tboo462.X

Liow, J. C. (20I7). Asia's Southern Tier dalam International Relations and Asia's Southern Tier. Singapore: Asan-Palgrave Macmillan.

Margaret E. Keck, \& Sikkink, K. (I999). Transnational advocacy networks in international and regional politics. Blacwell Publisher.

Margaret P Karns, Karen A Mingst, \& Stilles, K. W. (2015). International Organizations: The Politics and Processes of Global Governance (Third). Colorado: Lynne Rienner Publisher, Inc.

Martyn, H. L. (2018). Voices of Indonesian Migrant Workers at Home and Abroad. Canadian Center of Science and Education: Asian Social Science, I4(I8).

Migrant-Care. (2009). Sikap Migrant Care Terhadap Problematika Buruh Migran Indonesia. Migrant-Care.

Min-Hyung, K. (20II). Theorizing ASEAN Integration. Journal Asian Perspective, Vol 35.

Margiansyah, D. (20I8). Kekuatan Sosial Hukum: Menundukkan Negara Kekuatan Besar Melalui Institusi Multilateral Independen. Jurnal Penelitian Politik, I5(I), II5-I25.

Mitzen, J. (2005). Reading Habermas in Anarchy: Multilateral Diplomacy and Global Public Spheres. American Political Science Review, 99(3), 40I-4I7.

Munarman. (n.d.). Rekonstruksi Civil Society: Wacana dan Aksi Ornop di Indonesia (p. xxxiiii). Jakarta: Pustaka LP3ES Indonesia.

Nahar;, F. H., \& Arshad, M. N. M. (20I7). Effects of remittances on poverty reduction: The Case of Indonesia. Journal of Indonesian Economy and Business, 32(3), I63 - I77.

Neuman, W. L. (2006). Social Research Methods Qualitative and Quantitave Approaches. Boston: Pearson and AB.

No Title. (n.d.). Retrieved from http://www.ilo. org/wcmsp5/groups/public/---asia/---robangkok/documents/meetingdocument/ wcms_363139.pdf

Nuaraeni, et all. (2010). Regionalisme dalam Studi Hubungan Internasional. Yogyakarta: Pusta.

Organization, I. L. (2016). Migration in ASEAN in figures: The International Labour Migration Statistics (ILMS) Database in ASEAN. Bangkok.

Patricia J Campbell, Aran MacKinnon, \& Stevens, C. R. (20I0). An Introduction to Global Studies. West Sussex: Wiley-Blackwell.

Peoples, C. (2009). Critical Theorist and International Relations. In N. Crawford N. C. Jenny Edkins \& Vaughan-Williams (Ed.) (pp. 7-I8). Routledge.

Perbudakan Modern atas buruh migran Indonesia. (20I5). Retrieved from http://www.dw.com/ id/perbudakan-modern-atas-buruh-migranindonesia/a-I72436I7

Robert W. Cox, \& Sinclair, T. J. (1996). Approaches to World Order. Cambridge: Cambridge University Press. 
Rother;, S., \& Piper, N. (20I4). Alternative Regionalism from Below: Democratizing ASEAN's Migration Governance. International Migration, Wiley, 53(3). https://doi.org/Io.IIII/ imig.I2I82

Rother, S. (20I5). Democratizing ASEAN through "Alternative Regionalism"? The ASEAN Civil Society Conference and the ASEAN Youth Forum. ASIEN, 136, 98-II9.

Rother, S. (2018). ASEAN Forum on Migrant Labour: A space for civil society in migration governance at the regional level? Asia Pacific Viewpoint. https://doi.org/Io.IIII/apv.I2I8I

Rozman;, G., \& Liow, J. C. (20I7). International Relations and Asia's Southern Tier (p. 4). Singapore: Asan-Palgrave Macmillan.

Rüland;, J., \& Jetschke, A. (2008). 40 years of ASEAN: perspectives, performance and lessons for change. Routledge: The Pacific Review, 2I(4), 397-409.

Rüland, J. (2000). ASEAN and the Asian crisis: theoretical implications and practical consequences for Southeast Asian regionalism. The Pacifc Review, Vol. I3 No. 3, I3(3), 42I-45I.

Rüland, J. (20II). Southeast Asian Region and Global Governance: "Multilateral Utility" or "Hedging Utility? Contemporary Southeast Asia, Vol. 33(I), 83-II2.

Rupert, M. (2009). Critical Theorist and International Relations (pp. I76-I86). Ro.

Salvador Santino F. Regilme, J. (20I6). Habermasian Thinking on Civil Society and the Public Sphere in the Age of Globalization. Perspectives on Political Science.

Santoso, A. (2013). A two level sociological institutionalist critique of migrant workers protection: a state and regional analysis of Indonesia and the Philippines. University of Nottingham., Nothingham, UK. Retrieved from http:// eprints.nottingham.ac.uk/I4366/I/595856.pdf

Sayono;, J., Wahyu;, I., \& Ayundasari, L. (2018). Migrant workers and socio-economic changes. Masyarakat, Kebudayaan Dan Politik Vol. 3I, Issue 2, 20I8, Page I76-I89, 3I(2), I76-I89.

SBMI. (2014). Catatan Akhir Tahun 2014: Rekam Proses Pembelaan Kasus Buruh Migran dan Advokasi Kebijakan. (SBMI, Ed.).

Secretariat, A. (2009). ASEAN Socio-Cultural Community Blueprint. Jakarta: ASEAN Secretariat.

Simon, S. W. (2002). Evaluating Track II approaches to security diplomacy in the Asia-Pacific: the CSCAP experience. The Pacifc Review, I5(2), I67-200.
Slavery at sea: human traficking in the fishing industry exposed. (2015, June). Retrieved from http://www.scmp.com/magazines/ post-magazine/article/18I9562/slavery-seahuman-trafficking-fishing-industry-exposed

Solidaritas-Perempuan. (2015). Catatan Penanganan Kasus Solidaritas Perempuan Menggugat Tanggung Jawab Negara Atas Perlindungan Hak Buruh Migran Perempuan dan Anggota Keluarganya.

Solidaritas-Perempuan. (20I7). Kaleidoskop Kekerasan dan Pelanggaran Hak Perempuan Buruh Migran 20I6: Menagih Tanggung Jawab Negara Dalam Melindungi Perempuan Buruh Migran. Jakarta.

Spång, M. (20I7). Emancipation, Democracy and the Modern Critique of Law. (G. Browning, Ed.). Cham: Palgrave Macmillan. https://doi. org/10.1007/978-3-319-62890-5

Stahl, C. W. (I99I). South-North Migration in the Asia-Pacific Region. Internationl Migration (Vol. 29). https://doi.org/Io.IIII/j.I468-2435.I99I. tboioi3.x

Sthor, R. (2013). Toward a Global Organizational Public Sphere: Non-governmental Organizing and Democratic Legitimacy in a Postmodern World. The Graduate College at the University of Nebraska, Nebraska.

TFA. (2009, February). Statement to ASEAN S-G Surin Pitsuwan.

TFAMW. (2006a). Final Singapore Consulation Repor.

TFAMW. (2006b). Final Singapore Consultation Report: First Civil Society Organization-Trade Union Drafting the ASEAN Framework Instrument on the Rights of Migrant Worker.

TFAMW. (2007a). Final Bangkok Statement TF on Asian MWs and Thai \& Mekong Partners. Bangkok.

TFAMW. (2007b). Final Statement CSO-TU Dialogue: TFAMW Consultation workshop on protection and promotion of the rights of migrant workers, "forging and strengthening linkages among Migrant NGOs and Trade Unions."

TFAMW. (2007c). Statement on the ASEAN Declaration on the Protection and Promotion of the Rights of Migrant Workers. Retrieved from http://www.workersconnection.org/articles. php?more $=70$

TFAMW. (2008a). Final Statemet Cambodia National Consultation.

TFAMW. (2008b). FINAL Vietnam National Consultation Statement. Hanoi.

TFAMW. (2008c). Full Meeting Report SEARCHUNIFEM-Task Force. 
TFAMW. (2009). Civil Society Proposal: ASEAN Framework Instrument on the Protection and Promotion of the Rights of Migrant Workers.

TFAMW. (20II, October). the 4th ASEAN Forum on Migant Labor. Retrieved from http://workersconnection.org/articles.php?more $=\mathrm{I} 45$

TIFA-Foundation. (2018). "Perlindungan lemah, kasus buruh migran makin tinggi." Retrieved July 3, 20I9, from https://www.tifafoundation. org/perlindungan-lemah-kasus-buruhmigran-makin-tinggi/

Uhlin, A. (2016). Civil Society and Regional Governance: the ADB and ASEAN. London: Lexiton Books.

UNDESA. (20I7). International Migration Report 20I7: Highlights (ST/ESA/SER.A/404).

Weber, M. (2008). Constructivism and Critical Theory. In Richard Devetak Anthony Burke \& J. George (Eds.) (pp. 96-Io8). Cambridge: Cambridge University Press.
Wells-Dang, A., \& Wells-Dang, G. (20II). Civil Society in ASEAN: a healthy development? The Lancet, (377).

Wunderlich, J. U. (2007). Regionalism, Globalisation and International Order. Hampshire, England: Ashgate.

Yazid, S. (2013). Indonesia's Civil Society in the Age of Democratization: NGO-Responses on the Issue of Labor Migration. Nomos Verlagsgesellschaft.

Yazid, S. (2015). Indonesian Labour Migration: Identifying the Women. Jurnal Global \& Strategis, 9(I).

Yin, R. K. (2015). Studi Kasus Desain dan Metoder. Jakarta: RajaGrafindo Persada.

Zygadło, P. (2018). Cultural Particularism and Intercultural Communication: The Case of Chinese Face. IAFOR Journal of Cultural Studies, 3(2), 65-77. 